\title{
Effect of hyperoxic exposure on protein synthesis in the rat
}

Frank J. KELLY

School of Biochemical and Physiological Sciences, University of Southampton, Bassett Crescent East, Southampton SO9 3TU, U.K.

Rates of protein synthesis were measured in vitro in the lung and heart from fed rats exposed to hyperoxia $\left(\leqslant 95 \% \mathrm{O}_{2}\right.$ ) for either 6 or $24 \mathrm{~h}$. Protein synthesis rates were depressed by 16-32\% compared with normoxic controls in these tissues. The inhibition in both tissues was greatest after $24 \mathrm{~h}$ hyperoxic exposure. The decreased fractional rates of synthesis in both tissues were related to changes in ribosomal activity rather than capacity. The fall in synthesis rate per ribosome was greatest in both tissues when the exposure period was increased to $24 \mathrm{~h}$. The possible mechanism(s) involved in hyperoxia-induced depression of protein synthesis are discussed.

\section{INTRODUCTION}

It has been appreciated for a considerable time that high concentrations of oxygen are detrimental to many species (Lorraine-Smith, 1899; Bean, 1945). Exposure to $100 \%$ oxygen at normal atmospheric pressure will eventually cause death in most mammalian species. The primary site of injury is the lung, and death is associated with progressive pulmonary disfunction, characterized by increasing respiratory distress (Haugaard, 1968; Balentine, 1982).

One of the many deleterious effects induced by hyperoxia is an inhibition of protein synthesis. In cultured cells the rate of protein synthesis is dramatically decreased by oxygen partial pressures $\left(\mathrm{pO}_{2}\right)$ higher than $40 \%$ (Rueckert \& Mueller, 1960; Brosemer \& Rutter, 1961; Hollenberg, 1971; Grave et al., 1972; Goetz, 1975; Balin et al., 1976; Jornot \& Junod, 1985). It has also been reported that protein synthesis is inhibited in rabbit reticulocytes and derived lysates when exposed to high $\mathrm{pO}_{2}$ (Almis-Kanigur et al., 1982; Kanigur et al., 1983). However, few studies have considered the influence of hyperoxia at normal atmospheric pressure on protein synthesis in the lung. No study could be found in which the effect of hyperoxia has been monitored by determining the rate of pulmonary protein synthesis in vivo. Of those studies in vitro identified, protein synthesis was determined by incubating lung slices with $\left[{ }^{14} \mathrm{C}\right]$ leucine. After $12 \mathrm{~h}$ hyperoxic $(\geqslant 98 \%)$ exposure in vivo, no alteration in radiolabel incorporation was determined (Gacad \& Massaro, 1973). However, after 24 h hyperoxia a significant decrease in radiolabel incorporation was determined. This inhibition was further increased after $48 \mathrm{~h}$ exposure (Massaro, 1973). Although suggestive of an inhibitory effect on protein synthesis, the conclusions that can be drawn from those studies are limited, mainly by the inadequate methodology employed (see the Discussion section).

In the present investigation the 'in vivo' flooding dose method of Garlick et al. (1980) has been utilized to determine the acute $(6 \mathrm{~h})$ and chronic $(24 \mathrm{~h})$ effects of hyperoxic exposure on protein synthesis in the rat lung.

\section{EXPERIMENTAL}

Male Wistar rats (18; initial body wt. 110-120 g) were housed in a room controlled for temperature $\left(22^{\circ} \mathrm{C}\right)$ and having a daily photoperiod of $12 \mathrm{~h}$ light between 06:00 and 18:00 h. Animals were randomly divided into three groups, control, $6 \mathrm{~h}$-oxygen-exposed and $24 \mathrm{~h}$-oxygenexposed. Oxygen exposure was carried out in 25-litre Perspex cages supplied with humidified oxygen (BOC; medical grade) at a rate of 3 litres $/ \mathrm{min}$. Oxygen concentration was monitored continuously (IL 407 apparatus; Instrumentation Laboratory, Lexington, MA, U.S.A.); it varied between 94 and $96 \%$. The $\mathrm{CO}_{2}$ concentration was determined $1 \mathrm{~h}$ after the commencement of the experiment and just before the termination of each exposure; it never exceeded $0.5 \%$ (PA 404 instrument; Servomax, Crowborough, Sussex, U.K.). Relative humidity ranged from 50 to $70 \%$ and temperature between 23 and $25^{\circ} \mathrm{C}$. Control rats were kept in an identical cage supplied by room air. All animals were supplied with food and water ad libitum. The $24 \mathrm{~h}-\mathrm{O}_{2}-$ exposure period commenced at 14:00 h on day 0 and $6 \mathrm{~h}$ exposure started at $08: 00 \mathrm{~h}$ on day 1. All animals were injected with radiolabelled tracer and decapitated on a rotational basis between 13:00 and 16:00 $\mathrm{h}$ of day 1 .

Protein synthesis was measured in vivo after an intravenous bolus injection of phenylalanine to flood the precursor pool(s) (Garlick et al., 1980). For this procedure, rats were individually removed from their chamber, wrapped in a tea towel and injected via a lateral tail vein. The injection consisted of $150 \mu \mathrm{mol}$ of phenylalanine, including $65 \mu \mathrm{Ci}$ of $\mathrm{L}-\left[4-{ }^{3} \mathrm{H}\right]$ phenylalanine (sp. radioactivity $24 \mathrm{Ci} / \mathrm{mmol}$; The Radiochemical Centre, Amersham, Bucks., U.K.) in $1 \mathrm{ml}$ of $0.9 \% \mathrm{NaCl} /$ $100 \mathrm{~g}$ body wt. After injection animals were returned to their normoxic or hyperoxic environments for a further $9 \mathrm{~min}$. At $10 \mathrm{~min}$ exactly, animals were decapitated and blood was collected over the following $15 \mathrm{~s}$. After blood collection, lung and heart tissue were rapidly removed, frozen in liquid $\mathrm{N}_{2}$, weighed and stored at $-20^{\circ} \mathrm{C}$ until analysis. Sample preparation involved homogenizing tissue $(200 \mathrm{mg})$ in 5 vol. of ice-cold $0.2 \mathrm{M}-\mathrm{HClO}_{4}$ with a ground-glass homogenizer. The specific radioactivities of the phenylalanine both in the tissue pool(s) and covalently bound in protein were measured in these homogenates as described by Garlick et al. (1980). This involved the prior hydrolysis of the washed protein pellets in $6 \mathrm{M}$ $\mathrm{HCl}$ at $110^{\circ} \mathrm{C}$ for $24 \mathrm{~h}$ and the conversion of phenylalanine into $\beta$-phenethylamine (Garlick et al., 1980). Radioactivity measurements were made in a LKB 1219 scintillation counter after addition of Labscint scintillation fluid (Lablogic, Sheffield, U.K.), with the use of an 
Table 1. Free phenylalanine specific radioactivity of plasma, lung and heart in control and hyperoxic exposed rats

The specific radioactivities of both plasma and tissue free phenylalanine were determined as described by Garlick et al. (1980). Each value is the mean \pm S.E.M. for at least five individual tissues.

\begin{tabular}{llll}
\hline & \multicolumn{3}{c}{ Phenylalanine sp. radioactivity } \\
& \multicolumn{3}{c}{ (d.p.m./nmol) } \\
\cline { 2 - 4 } Treatment & Plasma & Lung & Heart \\
\hline & & & \\
Control & $750 \pm 12$ & $688 \pm 9$ & $671 \pm 17$ \\
$6 \mathrm{~h} \mathrm{O}_{2}$ & $762 \pm 16$ & $656 \pm 22$ & $690 \pm 12$ \\
$24 \mathrm{~h} \mathrm{O}_{2}$ & $781 \pm 15$ & $660 \pm 17$ & $650 \pm 27$ \\
\hline
\end{tabular}

external standard. The fractional rate of synthesis (i.e. $K_{\mathrm{s}}$, the percentage of the protein mass synthesized per day) was calculated from:

$$
K_{\mathrm{s}}=\frac{S_{\mathrm{B}}}{S_{\mathrm{A}} t} \times 100
$$

where $S_{\mathrm{A}}$ and $S_{\mathrm{B}}$ are the specific radioactivities of phenylalanine in the free tissue pool (i.e. intracellular and extracellular) and protein respectively, and $t$ is the time in days.

Protein concentration was measured in the same tissue by the method of Lowry et al. (1951), with bovine serum albumin as standard. RNA content was determined by alkaline hydrolysis as described by Fleck \& Munro (1962). A value of $A_{1 \mathrm{~cm}}^{32 \mu \mathrm{ml}}=1$ at $260 \mathrm{~nm}$ was used to calculate the concentration of hydrolysed RNA. The significance of differences between controls and hyperoxic exposed groups was tested by the two-tailed unpaired Student's $t$ test. Values of $P<0.05$ were taken as being statistically significant.

\section{RESULTS}

In a preliminary study, the effects of hyperoxic exposure $\left(\geqslant 95 \% \mathrm{O}_{2}\right)$ on whole-body and lung growth were assessed in the rat. After $48 \mathrm{~h}$ exposure, a decrease in body weight compared with room-air-exposed controls was observed. This decrease in whole-body growth was followed by a decrease in the rate of lung growth in these animals. During day 2 of hyperoxia, food consumption declined, falling from 12 to $2 \mathrm{~g}$ /day per animal by day 4 . As a result of the reported inhibitory effect of food deprivation on the protein-synthesis rate in several different tissues (Garlick et al., 1975; Waterlow et al., 1978), our subsequent experiments were designed to minimize the effects of food deprivation. In these experiments, the duration of hyperoxia did not exceed $24 \mathrm{~h}$, i.e. a period in which the food intakes of these animals were not significantly different from those of room-air-exposed animals.

As the methodology employed relies on certain assumptions (see Garlick et al., 1980) regarding the distribution of radiolabel, it was important to determine the effects (if any) of hyperoxic exposure on the pattern of radiolabel distribution. Table 1 shows that the plasma specific radioactivity at the time of killing was very similar in the three groups of animals. At 10 min after injection, $S_{\mathrm{A}}$ in both lung and heart had reached approx. $90 \%$ of the plasma value in each treatment group. These results indicate that hyperoxic exposure for either 6 or $24 \mathrm{~h}$ did not adversely affect the uptake of the phenylalanine radiolabel into these tissues.

Table 2 shows that after $6 \mathrm{~h}$ hyperoxia there was an appreciable $(20 \%)$ but non-significant decrease in the fractional rate of protein synthesis in the lung. However, when the total amount of protein synthesized per lung was calculated, it was found that those lungs exposed to $95 \%$ oxygen synthesized considerably less protein $(28 \%$ less). This decrease in protein synthesis may explain the lower amount of protein associated with lungs exposed for $6 \mathrm{~h}$ to the high oxygen (Table 2).

When animals were exposed for a continuous $24 \mathrm{~h}$ period to hyperoxia, the fractional rate of protein synthesis in the lung was further decreased, the rate being significantly lower than that in the control lungs. This decrease was reflected in the total rate of protein synthesis in the lung, which fell by $38 \%$ compared with the airexposed controls. RNA content in these same tissues was determined as described in the Experimental section. Table 2 shows that RNA content was not altered by hyperoxic exposure. When exposure on a protein basis, RNA concentration increased marginally, owing to the

Table 2. Protein and RNA contents and protein-synthesis rates in lung after hyperoxic exposure

Total protein (collagenous and non-collagenous) was measured by the method of Lowry et al. (1951). RNA was determined by alkaline hydrolysis as described by Fleck \& Munro (1962). The fractional synthesis rate of lung protein was determined as described by Garlick et al. (1980). The total amount of protein synthesized per day represents the product of the fractional rate and the protein mass. The efficiency of protein synthesis represents the total protein synthesized per day per mg of RNA. The values presented here are means \pm S.E.M. derived from at least five animals. Values in parentheses show the percentage change from the control group. Statistical significance for the hyperoxic group versus the control group is ${ }^{*} P<0.05,{ }^{* *} P<0.01$.

\begin{tabular}{|c|c|c|c|c|c|c|}
\hline Treatment & $\begin{array}{l}\text { Protein } \\
\text { content } \\
\text { (mg) }\end{array}$ & $\begin{array}{c}\text { RNA } \\
\text { content } \\
\text { (mg) }\end{array}$ & $\begin{array}{l}\text { RNA/ } \\
\text { protein } \\
(\mu \mathrm{g} / \mathrm{mg})\end{array}$ & $\begin{array}{c}\text { Fractional rate } \\
\text { of synthesis } \\
(\% / \text { day })\end{array}$ & $\begin{array}{c}\text { Total protein } \\
\text { synthesis } \\
\text { (mg/day) }\end{array}$ & $\begin{array}{l}\text { Efficiency of } \\
\text { protein synthesis } \\
\text { (mg/day per } \\
\text { mg of RNA) }\end{array}$ \\
\hline $\begin{array}{l}\text { Control } \\
6 \mathrm{~h} \mathrm{O}_{2}\end{array}$ & $\begin{array}{l}118.0 \pm 5.1 \\
107.0 \pm 4.7\end{array}$ & $\begin{array}{l}3.08 \pm 0.4 \\
3.19+0.2\end{array}$ & $\begin{array}{l}25.4 \pm 0.9 \\
27.9 \pm 1.8\end{array}$ & $\begin{array}{l}38.9 \pm 4.1 \\
31.0 \pm 2.3 \\
(-20 \%)\end{array}$ & $\begin{array}{l}44.7 \pm 1.8 \\
32.0 \pm 4.2^{*} \\
(-28 \%)\end{array}$ & $\begin{array}{c}13.7 \pm 0.6 \\
9.9 \pm 0.4^{*} \\
(-28 \%)\end{array}$ \\
\hline $24 \mathrm{~h} \mathrm{O}_{2}$ & $\begin{array}{l}99.5 \pm 3.2^{*} \\
(-16 \%)\end{array}$ & $3.04 \pm 0.3$ & $29.1 \pm 2.1$ & $\begin{array}{l}29.0 \pm 2.0^{*} \\
(-25 \%)\end{array}$ & $\begin{array}{l}27.7 \pm 2.3^{* *} \\
(-38 \%)\end{array}$ & $\begin{array}{l}8.7 \pm 0.3^{* *} \\
(-36 \%)\end{array}$ \\
\hline
\end{tabular}


Table 3. Protein and RNA contents and protein-synthesis rates in heart after hyperoxic exposure

Hearts were analysed in the same manner as described for the lung (Table 2). Similar samples (cross-sectional area from both ventricles) were removed for analysis from each animal. Results are expressed as means \pm S.E.M. Values in parentheses indicate the percentage change from the control group. Statistical significance for the hyperoxic group versus the control group is ${ }^{*} P<0.05,{ }^{* *} P<0.01$.

\begin{tabular}{|c|c|c|c|c|c|c|}
\hline Treatment & $\begin{array}{l}\text { Protein } \\
\text { content } \\
(\mathrm{mg})\end{array}$ & $\begin{array}{l}\text { RNA } \\
\text { content } \\
\text { (mg) }\end{array}$ & $\begin{array}{l}\text { RNA/ } \\
\text { protein } \\
(\mu \mathrm{g} / \mathrm{mg})\end{array}$ & $\begin{array}{c}\text { Fractional rate } \\
\text { of synthesis } \\
(\% / \text { day })\end{array}$ & $\begin{array}{l}\text { Total protein } \\
\text { synthesis } \\
(\mathrm{mg} / \text { day })\end{array}$ & $\begin{array}{l}\text { Efficiency of } \\
\text { protein synthesis } \\
\text { (mg/day per } \\
\text { mg of RNA) }\end{array}$ \\
\hline $\begin{array}{l}\text { Control } \\
6 \mathrm{~h} \mathrm{O}_{2}\end{array}$ & $\begin{array}{l}63.4 \pm 6.2 \\
64.5 \pm 5.1\end{array}$ & $\begin{array}{l}0.75 \pm 0.04 \\
0.71 \pm 0.08\end{array}$ & $\begin{array}{l}10.5 \pm 0.7 \\
10.6 \pm 0.4\end{array}$ & $\begin{array}{l}24.5 \pm 1.7 \\
20.6 \pm 0.9 \\
(-16 \%)\end{array}$ & $\begin{array}{l}16.1 \pm 2.2 \\
14.1 \pm 0.6 \\
(-12 \%)\end{array}$ & $\begin{array}{l}19.8 \pm 1.1 \\
17.4 \pm 0.8 \\
(-12 \%)\end{array}$ \\
\hline $24 \mathrm{~h} \mathrm{O}_{2}$ & $59.1 \pm 4.1$ & $0.68 \pm 0.07$ & $11.1 \pm 0.08$ & $\begin{array}{l}16.7 \pm 1.9^{* *} \\
(-32 \%)\end{array}$ & $\begin{array}{l}10.4 \pm 1.3^{*} \\
(-35 \%)\end{array}$ & $\begin{array}{l}14.8 \pm 1.0^{*} \\
(-25 \%)\end{array}$ \\
\hline
\end{tabular}

greater loss of protein in these tissues. When the total amount of lung protein synthesized per day was expressed on a RNA basis, it was found that the efficiency of synthesis was significantly decreased after both 6 and $24 \mathrm{~h}$ of hyperoxic exposure.

Table 3 shows that hyperoxic exposure produced a significant decrease in the fractional rate of synthesis in the heart. Exposure to $6 \mathrm{~h}$ hyperoxia resulted in a $10 \%$ fall, whereas $24 \mathrm{~h}$ exposure produced a $32 \%$ decrease in the fractional rate of cardiac protein synthesis. These changes were closely reflected by the total amount of protein synthesized by the heart after these treatments. As no change in RNA content or concentration was observed over this period, these changes in protein synthesis were reflected by a fall in the rate of protein synthesis per unit of RNA (Table 3 ).

\section{DISCUSSION}

It has been widely accepted for many years that hyperoxia induces a decrease in protein synthesis in several cell types (Rueckert \& Mueller, 1960; Brosemer \& Rutter, 1961; Hollenberg, 1971; Grave et al., 1972; Goetz, 1975; Balin et al., 1976; Jornot \& Junod, 1985). Before the present study, it was assumed from the work of Gacad \& Massaro (1973) that hyperoxia produced a similar response in the lung. In their studies in vitro, lung slices incubated with radiolabel were used to determine the rate of protein synthesis. However, the specific radioactivity of tissue-unbound radiolabel was not determined. Consequently the results that they obtained may not accurately reflect the protein-synthesis rate, as hyperoxia could additionally influence parameters which could in turn influence the specific radioactivity of the unbound precursor amino acid.

The present study was designed to re-address the question of whether hyperoxia influences the rate of protein synthesis in the lung. In this study, the 'in vivo' method of Garlick et al. (1980) has been used, to eliminate the methodological problems mentioned above [see Garlick et al. (1980) for further explanation]. The bolus dose method relies on the fact that all precursor pools are expanded and labelled to the same specific radioactivity within a short period after injection. Thereafter there is a small linear decrease in specific radioactivity over the incorporation period. Although these kinetics have been found consistently by many investigators previously (McNurlan et al., 1979; Garlick et al., 1980; Goldspink et al., 1984; Kelly et al., 1984), the effect(s) of hyperoxia on radiolabel distribution had not been considered. In the present study it was foud that exposure to $\geqslant 95 \% \mathrm{O}_{2}$ for up to $24 \mathrm{~h}$ did not change the distribution of phenylalanine. After injection of a bolus dose, the intracellular specific radioactivity, $S_{\mathrm{A}}$, in both lung and heart reached approx. $90 \%$ of the plasma value within 2 min (results not shown). It was clear from these initial studies that protein synthesis could be measured accurately in animals that had been exposed to hyperoxia with the current protocol.

In this study, evidence has been found to suggest that acute $(6 \mathrm{~h})$ exposure to hyperoxia leads to a decrease in protein synthesis in the lung. This inhibition in lung protein synthesis is further increased after extension of the exposure period to $24 \mathrm{~h}$.

Having observed these changes in protein synthesis in the lung after either 6 or $24 \mathrm{~h}$ hyperoxic exposure, it was decided to determine if the changes observed were confined to the lung, being the principal organ exposed to the stress, or whether they merely reflected a more general tissue response in these animals. To investigate this, protein-synthesis rates were determined in a second tissue in these same animals, the heart. Both the functional rate of synthesis and total protein synthesis in the heart were found to fall after $6 \mathrm{~h}$ hyperoxic exposure. These decreases were further substantiated after $24 \mathrm{~h}$ exposure. It therefore appears that hyperoxic exposure results in an inhibition of protein synthesis that is of similar magnitude in both these tissues.

As exposure to high oxygen concentration was inhibiting the rate of protein synthesis in these tissues, it was decided to determine the nature of the inhibition. The rate of protein synthesis depends on the number of ribosomes per cell and the activity of these ribosomes in the translational process. An index of ribosomal capacity can be obtained from RNA/protein values, and of ribosomal activity from synthesis per unit RNA (Henshaw et al., 1971; Waterlow et al., 1978). In the lung, the decline in the synthesis rate was accompanied not by any fall in the ribosomal capacity (i.e. RNA/protein), but rather by a decrease in ribosomal activity (i.e. synthesis/ RNA). In the heart a similar trend was observed, except a significant decrease in ribosomal activity was observed only after $24 \mathrm{~h}$ exposure.

The precise mechanism(s) operational in the hyperoxic 
inhibition of protein synthesis have not been investigated in this study. However, from the results obtained, a number of possible mechanisms may be postulated, which involve either a direct effect of oxygen on the nucleus or the cytoplasm, or a combination of both. It has previously been suggested that hyperoxia has a direct effect on the nucleus by inhibiting RNA and DNA synthesis (Rueckert \& Mueller, 1960; Brosemer \& Rutter, 1961; Northway et al., 1972, 1976). The decrease in pulmonary and cardiac protein synthesis after hyperoxia may therefore be due to decreased availability of mRNA in these tissues. On the other hand, hyperoxia may inhibit translation directly within the cytoplasm. Several studies have shown that hyperoxia itself can produce enzyme inactivation, especially those containing thiol groups (Haugaard, 1946; Jamieson et al., 1963). If any thiol-containing enzymes are directly involved in translation, then inactivation by reduction of disulphide links could lead to a decrease in the rate of protein synthesis.

In addition, hyperoxia may lead to an increased utilization of GSH in the lung. Among its many cellular functions, GSH acts as a substrate for glutathione peroxidase in the detoxification of $\mathrm{H}_{2} \mathrm{O}_{2}$ and lipid hydroperoxides. Under normal circumstances, GSSG produced in this reaction is recycled to GSH by the action of glutathione reductase. If the flux through this system is increased, as a result of hyperoxic exposure, it is feasible that the pool of GSSG in the lung may increase. GSSG is a potent inhibitor of protein synthesis in the reticulocyte and derived lysates (Kanigur et al., 1983). Studies with fractions derived from reticulocyte lysates have shown that exposure to either high $p \mathrm{O}_{2}$ or GSSG results in the activation of an inhibitor of protein synthesis. This inhibitor appears to be similar to the haem-controlled repressor ('HCR') and the high-pressure-activated inhibitor ('HPAI') (Kanigur et al., 1983).

These findings, if applicable to the lung, would suggest that the hyperoxia-induced changes in protein synthesis are mediated through a mechanism which involves the initiation factor eIF-2. Studies are needed to investigate the glutathione status of the lung and the nature of the translational block after hyperoxic exposure.

This work was supported by a grant from the University of Southampton. I am indebted to Denise Holden and Julia Fussell for their excellent technical assistance, and to Betty Draper for her assistance in the preparation of this manuscript.

Received 17 August 1987/28 October 1987; accepted 11 November 1987

\section{REFERENCES}

Almis-Kanigur, G., Kan, B., Kospancali, S. \& Bermek, E. (1982) FEBS Lett. 145, 143-146

Balentine, J. D. (1982) Pathology of Oxygen Toxicity, Academic Press, New York

Balin, A. K., Goodman, D. B. P., Rasmussen, H. \& Cristofalo, V. J. (1976) J. Cell. Physiol. 89, 235-250

Bean, J. (1945) Physiol. Rev. 25, 1-147

Brosemer, R. W. \& Rutter, W. J. (1961) Exp. Cell Res. 251, 101-103

Fleck, A. \& Munro, H. N. (1962) Biochim. Biophys. Acta 55, 571-583

Gacad, G. \& Massaro, D. (1973) J. Clin. Invest. 52, 559565

Garlick, P. J., Millward, D. J., James, W. P. T. \& Waterlow, J. C. (1975) Biochim. Biophys. Acta 414, 71-84

Garlick, P. J., McNurlan, M. A. \& Preedy, V. R. (1980) Biochem. J. 192, 719-723

Goetz, I. E. (1975) In Vitro 11, 382-394

Goldspink, D. F., Lewis, S. E. M. \& Kelly, F. J. (1984) Biochem. J. 217, 527-534

Grave, G. D., Kennedy, C. \& Sokoloff, L. (1972) J. Neurochem. 19, 187-194

Haugaard, N. (1946) J. Biol. Chem. 164, 265-270

Haugaard, N. (1968) Physiol. Rev. 48, 311-373

Henshaw, E. C., Hirsch, C. A., Morton, B. E. \& Hiatt, A. (1971) J. Biol. Chem. 246, 436-446

Hollenberg, M. (1971) Circ. Res. 28, 148-157

Jamieson, D., Ladner, K. \& Van Den Brenk, H. A. S. (1963) Aust. J. Exp. Biol. Med. Sci. 41, 491-497

Jornot, L. \& Junod, A. F. (1985) Experientia 41, 830

Kanigur, G., Kan, B., Tiryaki, D. \& Bermek, E. (1983) Biochem. Biophys. Res. Commun. 117, 135-140

Kelly, F. J., Lewis, S. E. M., Anderson, P. \& Goldspink, D. F. (1984) Muscle Nerve 7, 235-242

Lorraine-Smith, J. (1899) J. Physiol. (London) 24, 19-35

Lowry, O. H., Rosebrough, N. J., Farr, A. L. \& Randall, R. J. (1951) J. Biol. Chem. 193, 265-275

Massaro, D. (1973) Proc. Soc. Exp. Biol. Med. 143, 602-603

McNurlan, M. A., Tomkins, A. M. \& Garlick, P. J. (1979) Biochem. J. 178, 373-379

Northway, W. H., Petriceks, R. \& Shahinian, L. (1972) Pediatrics 50, 67-72

Northway, W. H., Rezeau, L., Petriceks, R. \& Bensch, K. G. (1976) Pediatrics 57, 41-46

Rueckert, R. R. \& Mueller, G. C. (1960) Cancer Res. 20, 944-949

Waterlow, J. C., Garlick, P. J. \& Millward, D. J. (eds.) (1978) Protein Turnover in Mammalian Tissues and in the Whole Body, pp. 463-466, North-Holland, Amsterdam 